\title{
Article
}

\section{The Effect of Declarations of Sustainability Reports on Financial Performances of Banks in Turkey}

\author{
Ömer Dinçer 1,* and Ayşenur Altınay 2,3 \\ 1 Institute Of Social Sciences, Uşak University, Uşak, Turkey; omerdincer@hotmail.com \\ 2 Civil Aviation and ve Cabin Services PR., Uşak University, Uşak, Turkey; aysenur.altinay@usak.edu.tr \\ 3 Department of Accounting and Finance, Faculty of Business Administration, Uşak University, Uşak, \\ Turkey; aysenur.altinay@usak.edu.tr \\ * Correspondence: omerdincer@gmail.com
}

\begin{abstract}
Banking sector is generally taken out of sample while the sustainability performance, and the financial performance are compared with each other. The core aim of this study is to analyze the effect of the declarations made in the cope of sustainability reports on the financial performance in the banking sector. Seven banks were included in the study which were placed at least one time in BIST Sustainability Index in between 2010-2017 years. Environment, human resources, product liability and community involvement were determined as sustainability criteria and return on assets, return on equity and net interest margin were determined as financial performance criteria. Non-Parametric Statistic Tests and Panel Data Analysis were used for analysis and types, and the sizes of banks were selected as dummy variables. As a result, it is found that the declarations of sustainability reports have a significant effect only on return on assets and have no significant effect on return on equity and net interest margin. And also, when we analyzed the relationship of sustainability criteria and return on assets, we found that the declarations about environment and human resources have negative effects on return on assets.
\end{abstract}

Keywords: banking; financial performance; sustainability performance

\section{Introduction}

Uncontrolled, rapid growth and consumption in the World jeopardize the sustainability of the generations after us. Because of that, the importance that the developed societies attached to sustainability issues like environmental consciousness and social responsibility and their awareness show a huge increase in recent years.

The totally profit oriented mind that the capitalism is forcing is being tried to balance by the concept of sustainable development for human being to maintain its development and to protect own wealth. In the report of World Commission on Environment and Development named "Our Common Future," it was emphasized that the concept of sustainable development should imply limits, and these limitations should be imposed by social organizations about environmental resources and present state of technology and by the ability of the biosphere to absorb the effects of human activities [25] (p. 16). After that, the concepts of sustainability and development started to be used together for the first time in the united nations environment and development conference in Rio De Janerio in the year 1992 [23] (p. 5).

After the concept of sustainable development gained recognition, the sustainability of companies became a current issue. And the issue that the usual financial reports which are prepared by companies are not sufficient for the sustainability of companies, came into view, because these reports like balance sheets, and income statements only give information about financial situation. The concept of institutional sustainability came up after this situation. It is targeted to create a longterm and permanent significance with institutional sustainability by customizing decision making mechanism of companies in three ways as economic, environmental, and social, which encompasses all shareholders [4] (p. 48). The first performance reporting in these three aspects is used under the 
name of institutional sustainability is stated by Elkington [10]. According to this report, the economic achievement should be parallel to environmental and social progress, and this relationship should be managed in a corporate way.

After the concept of institutional sustainability is bandied about, different kinds of sustainability reporting methods started to show up. According to the KPMG's report that published in 2013, 78 once of the biggest 100 companies are following any kind of sustainability report [18]. The most known and the common used one is the sustainability report which is prepared by the Global Reporting Investment (GRI).

Global Reporting Investment is an independent establishment, and they identify subjects and standards for companies to help them understanding and expressing themselves about sustainability issues as environment, human rights and corruption. GRI has led reporting on sustainability issues untill the end of $90^{\text {th }}$. [14]. As it is one of the most comprehensive guidebook and ensures the participation of shareholders widely, it became the most preferred sustainability report all over the World [19] (p. 101).

The concept of sustainability has gained importance in the middle of $2000^{\text {th. }}$. After the companies in BIST 30 Index were started to evaluate for BIST Sustainability Index in November of 2014, it became an important indicator for investors and the other shareholders.

The aim of this study is to determine the effect of declaration, which is made in the scope of sustainability reports in the Turkish banking sector on financial performance of banks. As we explained before, GRI reporting is the most widely used method in Turkey, in our study the banks which are publishing GRI reports in BIST Sustainability Index were selected for our sample.

\section{Literature}

There are lots of publications about sustainability performance in literature. However, after the beginning of 2000 by the progress in corporate sustainability awareness, much more companies started to publish sustainability reports. Afterwards indexes based on sustainability were established in national stock markets and the studies on sustainability performance turned to a different way.

The finance companies are mostly excluded in studies about sustainability performance as you see in Table 1. According to the table, when we check methods and results of publications, we see that Burhan \& Rahmanti [7], Madorran \& Garcia [20] could not find a relationship between sustainability performance and financial performance by the method panel data. Fernandez [11], Soytaş et al. [28], Düzer \& Önce [9] and Önder [22] found a positive relationship between sustainability performance and financial performance by the method panel data.

When we direct our attention to subtitles of sustainability, Düzer \& Önce [9] found a positive relationship between economic sustainability performance and financial performance in their study.

Table 1. Studies on Sustainability Performance

\begin{tabular}{|c|c|c|c|c|c|}
\hline No & Authors & Publication Name & Date & Sample & Methods \\
\hline 1 & $\begin{array}{l}\text { Annisa Hayatun N. } \\
\text { Burhan } \\
\text { Wiwin Rahmanti }\end{array}$ & $\begin{array}{c}\text { The Impact Of Sustainability } \\
\text { Reporting On Company } \\
\text { Performance }\end{array}$ & 2012 & $\begin{array}{l}32 \text { firms in } \\
\text { Indonesian } \\
\text { Stock Market }\end{array}$ & $\begin{array}{c}\text { Panel } \\
\text { Data } \\
\text { Analysis }\end{array}$ \\
\hline 2 & $\begin{array}{l}\text { Pérez-Calderón E., } \\
\text { Milanés-Montero P. } \\
\text { Ortega-Rossell F. J. }\end{array}$ & $\begin{array}{l}\text { Environmental } \\
\text { Performance and Firm Value: } \\
\text { Evidence from Dow Jones } \\
\text { Sustainability Index Europe }\end{array}$ & 2012 & $\begin{array}{l}122 \text { firms in } \\
\text { European } \\
\text { Dow Jones } \\
\text { Sustainability } \\
\text { Index }\end{array}$ & $\begin{array}{c}\text { Cluster } \\
\text { Analysis }\end{array}$ \\
\hline 3 & Priyanka Aggarwal & $\begin{array}{c}\text { Impact of Sustainability } \\
\text { Performance of Company on its } \\
\text { Financial Performance: A Study of } \\
\text { Listed Indian Companies }\end{array}$ & 2013 & $\begin{array}{l}20 \text { firms India } \\
\text { NIFTY } 50 \\
\text { Index }\end{array}$ & $\begin{array}{c}\text { Panel } \\
\text { Data } \\
\text { Analysis }\end{array}$ \\
\hline
\end{tabular}




\begin{tabular}{|c|c|c|c|c|c|}
\hline 4 & Sibel Fettahoğlu & $\begin{array}{l}\text { Relations between corporate social } \\
\text { responsibility and financial } \\
\text { performance: An application in } \\
\text { Istanbul stock exchange }\end{array}$ & 2014 & $\begin{array}{l}16 \text { firms in } \\
\text { BIST in Turkey }\end{array}$ & $\begin{array}{c}\text { Panel } \\
\text { Data } \\
\text { Analysis }\end{array}$ \\
\hline 5 & $\begin{array}{c}\text { Cristina Madorran, } \\
\text { Teresa Garcia }\end{array}$ & $\begin{array}{c}\text { Corporate Social Responsibility } \\
\text { And Financial Performance: The } \\
\text { Spanish Case }\end{array}$ & 2014 & $\begin{array}{l}35 \text { firms in } \\
\text { IBEX in Spain }\end{array}$ & $\begin{array}{c}\text { Panel } \\
\text { Data } \\
\text { Analysis }\end{array}$ \\
\hline 6 & $\begin{array}{c}\text { Mercedes } \\
\text { Rodriguez- } \\
\text { Fernandez }\end{array}$ & $\begin{array}{c}\text { Social responsibility and financial } \\
\text { performance: } \\
\text { The role of good corporate } \\
\text { governance }\end{array}$ & 2015 & $\begin{array}{l}121 \text { firms in } \\
\text { Madrid Stock } \\
\text { Exchange }\end{array}$ & $\begin{array}{c}\text { Panel } \\
\text { Data } \\
\text { Analysis }\end{array}$ \\
\hline 7 & $\begin{array}{c}\text { Paula Santis, } \\
\text { Andrei } \\
\text { Albuquerque, } \\
\text { Fabiane Lizarelli }\end{array}$ & $\begin{array}{c}\text { Do sustainable companies have a } \\
\text { better financial performance? } \\
\text { A study on Brazilian public } \\
\text { companies }\end{array}$ & 2016 & $\begin{array}{l}\text { Brazilian } \\
\text { Stock } \\
\text { Exchange } \\
\text { firms } \\
\text { (BM\&FBOVES } \\
\text { PA) }\end{array}$ & $\begin{array}{l}\text { Cluster } \\
\text { Analysis }\end{array}$ \\
\hline 8 & $\begin{array}{l}\text { Mehmet Ali Soytaş } \\
\text { Meltem Denizel } \\
\text { Damla Durak Uşar } \\
\text { İris Ersoy }\end{array}$ & $\begin{array}{c}\text { Corporate sustainability } \\
\text { investments and financial } \\
\text { Performance relationship in Turkey }\end{array}$ & 2017 & $\begin{array}{l}214 \text { firms in } \\
\text { BIST in Turkey }\end{array}$ & $\begin{array}{c}\text { Panel } \\
\text { Data } \\
\text { Analysis }\end{array}$ \\
\hline 9 & $\begin{array}{c}\text { Murat Düzer, } \\
\text { Saime Önce }\end{array}$ & $\begin{array}{c}\text { Effect of disclosures on } \\
\text { sustainability performance } \\
\text { indicators on financial } \\
\text { performance: An application in } \\
\text { BIST }\end{array}$ & 2018 & $\begin{array}{l}\text { GRI reporting } \\
30 \text { firms in } \\
\text { BIST }\end{array}$ & $\begin{array}{c}\text { Panel } \\
\text { Data } \\
\text { Analysis }\end{array}$ \\
\hline 10 & Şerife Önder & $\begin{array}{l}\text { Impact Of Sustainability } \\
\text { Performance Of Company On Its } \\
\text { Financial Performance: An } \\
\text { Empirical Study On Borsa Istanbul } \\
\text { (BİST) }\end{array}$ & 2018 & $\begin{array}{l}33 \text { firms in } \\
\text { BIST in Turkey }\end{array}$ & $\begin{array}{c}\text { Panel } \\
\text { Data } \\
\text { Analysis }\end{array}$ \\
\hline
\end{tabular}

*There is no finance company in the sample of studies.

Madorran \& Garcia [20], Düzer \& Önce [9] and Önder [22] found a positive relationship between environmental sustainability performance and financial performance but Aggarwal (2013) found a negative relationship between environmental sustainability performance and financial performance in their studies.

Burhan \& Rahmanti [7] found a relationship between sustainability performance and financial performance and Fettahoğlu [12] could not find a relationship between social sustainability performance and financial performance, Önder [22] found a positive relationship between social sustainability performance and financial performance in their studies.

Publications about sustainability and banks are summarized in Table 2. According to the table, we see that Multi-Criteria Decision-Making Models and statistical comparison methods were used to compare banks, on the other hand; panel data analysis was used to find out the effect of relations between sustainability and banks. 
Table 2. Studies on Sustainability and Banking

\begin{tabular}{|c|c|c|c|c|c|}
\hline No & Authors & Publication Name & Date & Sample & Methods \\
\hline 1 & $\begin{array}{l}\text { Kılıç, M., } \\
\text { Kuzey, C. } \\
\text { Uyar, A }\end{array}$ & $\begin{array}{l}\text { The Impact of Ownership and Board } \\
\text { Structure on Corporate Social } \\
\text { Responsibility (CSR) Reporting in the } \\
\text { Turkish Banking Industry }\end{array}$ & 2015 & $\begin{array}{l}25 \text { banks } \\
\text { operating in } \\
\text { Turkey }\end{array}$ & $\begin{array}{c}\text { Panel } \\
\text { Data } \\
\text { Analysis }\end{array}$ \\
\hline 2 & $\begin{array}{l}\text { Sonia Rebai, } \\
\text { Mohamed Naceur } \\
\text { Azaiez, Dhafer } \\
\text { Saidane }\end{array}$ & $\begin{array}{l}\text { A multi-attribute utility model for } \\
\text { generating a sustainability index in } \\
\text { the banking sector }\end{array}$ & 2015 & $\begin{array}{l}3 \text { biggest } \\
\text { banks in } \\
\text { France }\end{array}$ & AHP \\
\hline 3 & $\begin{array}{l}\text { Ayşenur Altınay } \\
\text { Barış Kaki } \\
\text { Ali Kestane } \\
\text { Mustafa Soba } \\
\text { Ömer Dinçer } \\
\text { Eser Şı }\end{array}$ & $\begin{array}{l}\text { The effects of sustainability index on } \\
\text { banking sector share center values, } \\
\text { an investigation on the BIST } \\
\text { sustainability index }\end{array}$ & 2017 & $\begin{array}{l}4 \text { banks in } \\
\text { BIST } \\
\text { Sustainabilit } \\
\text { y Index in } \\
\text { Turkey }\end{array}$ & $\begin{array}{l}\text { Pearson } \\
\text { Correlatio } \\
\text { n } \\
\text { Analysis, } \\
\text { Paired t- } \\
\text { test }\end{array}$ \\
\hline 4 & $\begin{array}{l}\text { Güler Aras } \\
\text { Nuray Tezcan } \\
\text { Özlem Kutlu } \\
\text { Furtuna }\end{array}$ & $\begin{array}{l}\text { Comparison of corporate } \\
\text { sustainability performance of } \\
\text { conventional and participation } \\
\text { banking with TOPSIS method }\end{array}$ & 2017 & $\begin{array}{l}7 \text { banks } \\
\text { operating in } \\
\text { Turkey }\end{array}$ & TOPSIS \\
\hline 5 & $\begin{array}{l}\text { Utku Şendurur ve } \\
\text { Fatma Temelli }\end{array}$ & $\begin{array}{l}\text { Comparison of participation and } \\
\text { conventional banks which are } \\
\text { operating in Turkey in terms of } \\
\text { sustainability }\end{array}$ & 2018 & $\begin{array}{c}5 \\
\text { participation } \\
\text { and } 7 \\
\text { conventional } \\
\text { banks } \\
\text { operating in } \\
\text { Turkey }\end{array}$ & t-test \\
\hline 6 & Amina Buallay & $\begin{array}{c}\text { Is sustainability reporting (ESG) } \\
\text { associated with performance? } \\
\text { Evidence from the European } \\
\text { banking sector }\end{array}$ & 2018 & $\begin{array}{l}235 \text { banks } \\
\text { operating in } \\
\text { European } \\
\text { Union }\end{array}$ & $\begin{array}{c}\text { Panel } \\
\text { Data } \\
\text { Analysis }\end{array}$ \\
\hline 7 & $\begin{array}{c}\text { Łukasz Matuszak } \\
\text { Ewa Rózanska }\end{array}$ & $\begin{array}{l}\text { A Non-Linear and Disaggregated } \\
\text { Approach to Studying the Impact of } \\
\text { CSR on accounting Profitability: } \\
\text { Evidence from the Polish Banking } \\
\text { Industry }\end{array}$ & 2019 & $\begin{array}{l}18 \text { banks } \\
\text { operating in } \\
\text { Poland }\end{array}$ & $\begin{array}{c}\text { Panel } \\
\text { Data } \\
\text { Analysis }\end{array}$ \\
\hline 8 & $\begin{array}{c}\text { Eriana } \\
\text { Kartadjumena } \\
\text { Waymond Rodgers }\end{array}$ & $\begin{array}{c}\text { Executive Compensation, } \\
\text { Sustainability, Climate, } \\
\text { Environmental Concerns, and } \\
\text { Company Financial Performance: } \\
\text { Evidence from Indonesian } \\
\text { Commercial Banks }\end{array}$ & 2019 & $\begin{array}{l}39 \\
\text { commercial } \\
\text { banks } \\
\text { operating in } \\
\text { India }\end{array}$ & $\begin{array}{c}\text { Panel } \\
\text { Data } \\
\text { Analysis }\end{array}$ \\
\hline
\end{tabular}

When we check the studies in which panel data analysis was used to find out relations between sustainability performance and financial performance, we see that Buallay [6] found a positive relationship in general, Matuszak \& Rózanska [21] couldn't find a relationship in general and Kartadjumena \& Rodgers [16] found a negative relationship in general. As you see, these studies couldn't find a common relationship between sustainability performance and financial performance in the banking sector. And also the number of the studies are still too less. 


\section{Implementation}

\subsection{Aim and Method}

The studies about sustainability in the finance sector is limited in literature. And most of the studies excluded finance sector from their samples [1, 7, 28]. The reason for this is that the responsibilities of finance sector concerning pollution and labor safety are less in contrast to other sectors. And also the financial performance indicators of the finance sector are different than other sectors. Because of that, the finance sector and the other sectors should not be in the same samples. But finance sector has an important role on assigning social and environmental politics of industries [17] (p. 360). Although the studies on the sustainability performances in banking sectors are increasing, it seems still unsatisfactory.

\subsection{Data Set and Sample Size}

Seven banks which were placed in BIST Sustainability Index, were included in the study. These banks were selected for our sample according to the criteria to be at least one time in BIST Sustainability Index between 2010-2017 years.

As it is seen in Table 3, two public and five private banks were used in our study. The public banks are Halk Bank and Vakıflar Bank, the private banks are İs Bank, Garanti Bank, TSKB, Akbank and Yapi Kredi Bank. Banks were also separated into 3 groups according to their asset sizes.

Table 3. Groups of Banks According To Types and Asset Sizes

Types

\begin{tabular}{cc}
\hline Public & Private \\
\hline 2 & 5 \\
\hline
\end{tabular}

Asset Sizes

\begin{tabular}{ccc}
\hline 0-180 Billions & $\mathbf{1 8 0 - 2 5 0}$ Billions & 250-320 Billions \\
\hline 2 & 3 & 2 \\
\hline
\end{tabular}

\subsubsection{Dependent Variables}

Accounting based financial indicators were used as dependent variables. These are return on assets (ROA), return on equity (ROE), net interest margin (NIM) which are financial indicators of banks, and those are used to measure banks financial performance [29] (p. 71-72).

\subsubsection{Independent Variables}

The independent variables of this study are the performance values that were calculated by using banks sustainability reports. These performance values were split up into four main groups. These are environment, human resources, product liability and community involvement.

The performance values were calculated for these groups by using a scoring model. This scoring model were explained below [16] (p. 9), [21] (p. 9);

About these 4 groups;

- If there isn't any explanation - Point 0

- If there is a partial explanation - Point 1

- If there is a full explanation - Point 2 was given.

\subsection{Hypotheses}

This study accorporates two main hypotheses and these hypotheses have sub-hypotheses. These were given below.

1. The hypotheses which are testing the performance value of sustainability reports differ or not according to types and sizes of banks

$\mathbf{H}_{1}$ : Sustainability performance of the banks differs according to the types of banks 
$\mathbf{H}_{2}$ : Sustainability performance of the banks differs according to the sizes of banks

2. The hypotheses which are testing the performance value of sustainability reports affects or not financial performance of banks

$\mathbf{H}_{3}$ : Sustainability performance of the banks has favorable effects on return on assets (ROA) of banks

$\mathbf{H}_{3 a}$ : Sustainability performance of the banks affects return on assets (ROA) of banks when we add types of banks as a dummy variable

$\mathbf{H}_{3 \mathrm{~b}}$ : Sustainability performance of the banks affects return on assets (ROA) of banks when we add sizes of banks as a dummy variable.

$\mathbf{H}_{4}$ : Sustainability performance of the banks has favorable effects on return on equity (ROE) of banks

$\mathbf{H}_{4 a}$ : Sustainability performance of the banks affects return on equity (ROE) of banks when we add types of banks as a dummy variable

$\mathbf{H}_{4 b}$ : Sustainability performance of the banks affects return on equity (ROE) of banks when we add sizes of banks as a dummy variable.

$\mathbf{H}_{5}$ : Sustainability performance of the banks has favorable effects on net interest margin (NIM) of banks

$\mathrm{H}_{5 a}$ : Sustainability performance of the banks affects net interest margin (NIM) of banks when we add types of banks as a dummy variable

$\mathrm{H}_{5 b}$ : Sustainability performance of the banks affects net interest margin (NIM) of banks when we add sizes of banks as a dummy variable.

\subsection{Methods}

The appropriate intra group difference test should be applied to test hypothesis $\mathrm{H}_{1}$ and $\mathrm{H}_{2}$. Initially, Kolmagorov Simirnov test was applied to understand if the data sets are normally distributed or not for determining the necessary methods. After we recognized that the data sets are not normally distributed Mann Whitney-U test was decided to apply identifying the difference between public and private banks. And also Kruskal-Wallis test was decided to apply identifying the difference between sizes of banks.

Panel Data Analysis was preferred for testing hypothesis $\mathrm{H}_{3}, \mathrm{H}_{4}, \mathrm{H}_{5}$ and their sub-hypothesis. Panel data is a kind of analysis that consists of time series and cross sections of observations over time on a (usually large) number of cross-sectional units like individuals, households, firms, or governments [5] (p. 1). The distinction of this method is the effect of numerically non-describable, non-observable or non-measurable factors can be measured with this method, and it identifies and measure effects that are simply not detectable in pure cross-section or pure time-series, more comprehensive and more consistent [15] (p. 7).

It is called balanced panel when the cross sections have the same number of time series [30] (p. 250). In this research, the panel data is a balanced panel.

There are some steps to apply panel data analysis, and these steps are explained briefly below.

\subsubsection{Unit Root Tests}

The time series should be stationary before they are put in the process. The stationarity in time series or in other words, involving unit root affects reliability of studies. The second generation unit root tests, named Levin, Lin \& Chu-t test (LLC), Im, Peseran \& Shin-W test (IPS), ADF-Fisher Chisquare test and PP -Fisher Chi-square tests are used to check the stationarity in our data sets. 
Table 4. Unit Root Test Results

\begin{tabular}{cccccccc}
\hline Methods & Env & HR & PL & CI & ROA & ROE & NIM \\
\hline \multirow{2}{*}{ LLC } & Normal & 1. & 1. & 1. & 1. & 1. & 2. \\
& Set & Difference & Difference & Difference & Difference & Difference & Difference \\
\multirow{2}{*}{ IPS } & Normal & 1. & 1. & 1. & 1. & 1. & 2. \\
& Set & Difference & Difference & Difference & Difference & Difference & Difference \\
& Normal & 1. & 1. & 1. & 1. & 1. & 2. \\
& Set & Difference & Difference & Difference & Difference & Difference & Difference \\
& Normal & 1. & 1. & 1. & 1. & 1. & 2. \\
& Set & Difference & Difference & Difference & Difference & Difference & Difference \\
\hline
\end{tabular}

As it is seen in Table 4, only the environment variable does not have unit root according to four different unit root tests. Human resources, product liabilities, community involvement, return on assets and return on equity variables became stationary in all tests after the first differences of sets. And net interest margin became stationary after the secondary difference. After that steps the human resources, product liabilities, community involvement, return on assets and return on equity variables were used with their first difference and net interest margin was used with its second difference in other steps.

\subsubsection{Selecting the Panel Data Model}

In this step, Hausman \& Breusch-Pagan LM tests were used to determine which models suited the best between pooled regression, fixed effect and the random effect models [13] (p. 301). According to the test result pooled regression model is approved to use. The models are formulized with pooled regression models as below.

ROA: $R O A_{i t+1}=\alpha+\beta_{1} E N V_{i t}+\beta_{2} H R_{i t}+\beta_{3} P L_{i t}+\beta_{4} C I_{i t}+\varepsilon_{i t}$

1. Model with Type of Banks Dummy Variable

$$
R O A_{i t+1}=\alpha+\beta_{1} E N V_{i t}+\beta_{2} H R_{i t}+\beta_{3} P L_{i t}+\beta_{4} C I_{i t}+\beta_{5} \text { Types }_{i t}+\varepsilon_{i t}
$$

2. Model with Size of Banks Dummy Variables

$$
R O A_{i t+1}=\alpha+\beta_{1} E N V_{i t}+\beta_{2} H R_{i t}+\beta_{3} P L_{i t}+\beta_{4} C I_{i t}+\beta_{5} \text { Sizes }_{i t}+\varepsilon_{i t}
$$

ROE: $R O E_{i t+1}=\alpha+\beta_{1} E N V_{i t}+\beta_{2} H R_{i t}+\beta_{3} P L_{i t}+\beta_{4} C I_{i t}+\varepsilon_{i t}$

1. Model with Type of Banks Dummy Variable

$$
R O E_{i t+1}=\alpha+\beta_{1} E N V_{i t}+\beta_{2} H R_{i t}+\beta_{3} P L_{i t}+\beta_{4} C I_{i t}+\beta_{5} \text { Types }_{i t}+\varepsilon_{i t}
$$

2. Model with Size of Banks Dummy Variables

$$
R O E_{i t+1}=\alpha+\beta_{1} E N V_{i t}+\beta_{2} H R_{i t}+\beta_{3} P L_{i t}+\beta_{4} C I_{i t}+\beta_{5} \text { Sizes }_{i t}+\varepsilon_{i t}
$$

NIM: $N I M_{i t+1}=\alpha+\beta_{1} E N V_{i t}+\beta_{2} H R_{i t}+\beta_{3} P L_{i t}+\beta_{4} C I_{i t}+\varepsilon_{i t}$

1. Model with Type of Banks Dummy Variable

$$
N I M_{i t+1}=\alpha+\beta_{1} E N V_{i t}+\beta_{2} H R_{i t}+\beta_{3} P L_{i t}+\beta_{4} C I_{i t}+\beta_{5} \text { Types }_{i t}+\varepsilon_{i t}
$$

2. Model with Size of Banks Dummy Variables

$$
N I M_{i t+1}=\alpha+\beta_{1} E N V_{i t}+\beta_{2} H R_{i t}+\beta_{3} P L_{i t}+\beta_{4} C L_{i t}+\beta_{5} \text { Sizes }_{i t}+\varepsilon_{i t}
$$




\section{Findings}

This stage consists of two parts. In the first part, it was tested if the declarations of sustainability reports, which are published by banks about environment, human resources, product liabilities and community involvement differ according to the types and the sizes of banks, by non-parametric statistical tests as Mann-Whitney $U$ and Kruskal Wallis. In the second part, the effect of these sustainability declarations' performance on return on assets, return on equity and net interest margin was analyzed separately with pooled regression panel data analysis.

The models in which only the sustainability performance values are independent variables were analyzed first, then the dummy variables (types and sizes of banks) were added to the models and analyzed again.

\subsection{Hypotheses Tests}

Hypothesis 1: Sustainability performance of the banks differs according to the types of banks.

To test $\mathrm{H}_{1}$ Mann-Whitney $\mathrm{U}$ test was applied. The hypothesis was rejected according to the test result in Table 5, because the p-value of total sustainability is 0,054 , and it is not significant at 0,05 significance level.

Table 5. Mann-Whitney U Test Result

\begin{tabular}{lcrrrr}
\hline & Env & HR & PL & \multicolumn{1}{c}{ CI } & Total Sust. \\
\hline Mann-Whitney U & 274,0000 & 292,0000 & 307,5000 & 338,0000 & 283,5000 \\
Wilcoxon W & 445,0000 & 463,0000 & 478,5000 & 509,0000 & 454,5000 \\
Z & $-2,0778$ & $-1,7936$ & $-1,5618$ & $-1,1295$ & $-1,9266$ \\
p & $0,0377^{* *}$ & 0,0729 & 0,1183 & 0,2587 & 0,0540 \\
\hline \multicolumn{5}{r}{ ** Statistically significant at \%5 significance level. }
\end{tabular}

Hypothesis 2: Sustainability performance of the banks differs according to the sizes of banks

To test $\mathrm{H}_{2}$ Kruskal-Wallis test was applied. The hypothesis was accepted according to the test result in Table 6, because the p-value of total sustainability is 0,012 , and it is significant at 0,05 significance level.

Table 6. Kruskal Wallis Test Results

\begin{tabular}{lrrrrr}
\hline & Env & HR & PL & CI & Total Sust. \\
\hline Chi-square & 6,8295 & 5,8262 & 7,0689 & 6,4170 & 8,8442 \\
df & 2,0000 & 2,0000 & 2,0000 & 2,0000 & 2,0000 \\
$\mathbf{p}$ & $0,0329^{* *}$ & 0,0543 & $0,0292^{* *}$ & $0,0404^{* *}$ & $0,0120^{* *}$ \\
\hline \multicolumn{7}{c}{ ( Statistically } & significant at $\% 5$ & significance level.
\end{tabular}

Hypothesis 3: Sustainability performance of the banks has favorable effects on return on assets (ROA) of banks

To test $\mathrm{H}_{3}$ Pooled OLS Regression Model is used for Panel data analysis.

Table 7. The Effect of Sustainability Performance on Return on Assets

\begin{tabular}{l} 
Dependent Variable: ROA \\
Total Panel Observations: 49 \\
Panel Data Status: Balanced \\
Method: Polled OLS Regression Model \\
White cross-section standard errors \& covariance (d.f. corrected) \\
\hline Independent Variables $\quad$ Coef. Std. Error t sta. p value
\end{tabular}




\begin{tabular}{lrrrr}
\hline Environment & $-0,0011$ & 0,0005 & $-2,3562$ & $0,0230^{* *}$ \\
Human Resources & $-0,0017$ & 0,0008 & $-2,0204$ & $0,0495^{* *}$ \\
Product Liability & 0,0013 & 0,0007 & 1,9528 & 0,0572 \\
Community Involvement & $-0,0007$ & 0,0007 & $-0,9222$ & 0,3614 \\
Constant Term ( C ) & 0,0001 & 0,0005 & 0,2126 & 0,8326 \\
\hline $\mathbf{R}^{2}$ & 0,2197 & & & \\
F statistic & 3,0964 & & & \\
p value of F statistic & 0,0249 & & & \\
Breusch-Pagan / C-W test value & 0,2903 & & & \\
White Test value & 0,3782 & & & \\
\hline
\end{tabular}

** Statistically significant at $\% 5$ significance level.

When we analyze the data summary in Table 7 , we see that our panel data is significant, because the $\mathrm{p}$-value of $\mathrm{F}$ statistic is less than 0,05 . And $\mathrm{R}^{2}$ value shows us that the independent variables can explain almost 22 percent of the changing in return on assets. In addition, the result of Breusch-Pagan Cook-Weisberg and White tests prove that there is no Heteroskedasticity in our model.

It is seen that environment and human resources have a significant effect on return on assets when we analyze the effect of independent variables (Environment, human resources, product liability and community involvement) on return on assets. And the direction of this impact is negative. And moreover, the intensity of environment's effect is 0,0011 , and the intensity of human resources effect is 0,0017 . According to this test result, $\mathrm{H}_{3}$ is rejected.

Hypothesis 3a: Sustainability performance of the banks affects return on assets (ROA) of banks when we add types of banks as a dummy variable.

To test $\mathrm{H}_{3 a}$ Pooled OLS Regression Model is used for Panel data analysis.

Table 8. The Effect of Sustainability Performance with Type of Banks on Return on Assets

\section{Dependent Variable: ROA}

Total Panel Observations: 49

Panel Data Status: Balanced

Method: Polled OLS Regression Model

White cross-section standard errors \& covariance (d.f. corrected)

\begin{tabular}{lrrrr}
\hline Independent Variables & Coef. & Std. Error & \multicolumn{1}{l}{ t sta. } & p value \\
\hline Environment & $-0,0015$ & 0,0006 & $-2,2690$ & $0,0283^{* *}$ \\
Human Resources & $-0,0016$ & 0,0008 & $-1,8851$ & 0,0662 \\
Product Liability & 0,0012 & 0,0007 & 1,6812 & 0,1000 \\
Community Involvement & $-0,0006$ & 0,0007 & $-0,8958$ & 0,3753 \\
Type of Banks & 0,0009 & 0,0007 & 1,3617 & 0,1804 \\
Constant Term ( C ) & $-0,0004$ & 0,0008 & $-0,4719$ & 0,6394 \\
\hline $\mathbf{R}^{2}$ & 0,2316 & & & \\
F statistic & 2,5926 & & & \\
p value of F statistic & 0,0390 & & & \\
Breusch-Pagan / C-W test value & 0,2389 & & & \\
White Test value & $* *$ Statistically significant at $\% 5$ significance level. & & \\
\hline
\end{tabular}

When we analyze the data summary in Table 8, we see that our panel data is significant, because the p-value of $\mathrm{F}$ statistic is less than 0,05 . And $\mathrm{R}^{2}$ value shows us that the independent variables can 
explain almost 23 percent of the changing in return on assets. This shows that when we add type of banks in the model, the model can explain more changes in return on assets. Furthermore, the result of Breusch-Pagan Cook-Weisberg and White tests prove that there is no Heteroskedasticity in our model.

It is seen that only environment has a significant effect on return on assets when we analyze the effect of independent variables (Environment, human resources, product liability and community involvement) on return on assets. And the direction of this impact is negative. And also, the intensity of environment's effect is 0,0015 . According to this test result $\mathrm{H}_{3 \mathrm{a}}$ is accepted.

Hypothesis 3b: Sustainability performance of the banks affects return on assets (ROA) of banks when we add sizes of banks as a dummy variable.

To test $\mathrm{H}_{3 b}$ Pooled OLS Regression Model is used for Panel data analysis.

Table 9. The Effect of Sustainability Performance with Size of Banks on Return on Assets

Dependent Variable: ROA
Total Panel Observations: 49
Panel Data Status: Balanced

Method: Polled OLS Regression Model

White cross-section standard errors \& covariance (d.f. corrected)

\begin{tabular}{lrrrr}
\hline Independent Variables & Coef. & Std. Error & \multicolumn{1}{l}{ t sta. } & \multicolumn{1}{c}{ p value } \\
\hline Environment & $-0,0010$ & 0,0004 & $-2,1892$ & $0,0341^{* *}$ \\
Human Resources & $-0,0017$ & 0,0008 & $-2,0717$ & $0,0443^{* *}$ \\
Product Liability & 0,0012 & 0,0006 & 1,9401 & 0,0589 \\
Community Involvement & 0,0007 & 0,0006 & $-1,0919$ & 0,2809 \\
Size of Banks & $-0,0005$ & 0,0003 & $-1,6847$ & 0,0993 \\
Constant Term ( C) & 0,0006 & 0,0006 & 1,0815 & 0,2855 \\
\hline $\mathbf{R}^{2}$ & 0,2361 & & & \\
F statistic & 2,6574 & & & \\
p value of F statistic & 0,0352 & & & \\
Breusch-Pagan / C-W test value & 0,1976 & & & \\
White Test value & ** Statistically significant at $\% 5$ significance level. & & \\
\hline & & & &
\end{tabular}

When we analyze the data summary in Table 9, we see that our panel data is significant, because the p-value of $F$ statistic is less than 0,05 . And $R^{2}$ value shows us that the independent variables can explain almost 24 percent of the changing in return on assets. This shows that when we add size of banks in the model, the model can explain more changes in return on assets. In addition, the result of Breusch-Pagan Cook-Weisberg and White tests prove that there is no Heteroskedasticity in our model.

It is seen that only environment and human resources have a significant effect on return on assets when we analyze the effect of independent variables (Environment, human resources, product liability and community involvement) on return on assets. And the direction of this impact is negative. And moreover, the intensity of environment's effect is 0,0010 , and the intensity of human resources effect is 0,0017 . According to this test result $\mathrm{H}_{3 a}$ is accepted.

To test $\mathrm{H}_{4}, \mathrm{H}_{4}, \mathrm{H}_{4 b}, \mathrm{H}_{5}, \mathrm{H}_{5}$ and $\mathrm{H}_{5 b}$ Pooled OLS Regression Model was used for Panel data analysis. As it is seen in Table 10, because of all the $\mathrm{p}$ values of $\mathrm{F}$ statistic for these hypotheses are more than 0,05 , these panel data's are not significant. According to that results from all other hypothesis are rejected. 
Table 10. Significance Values of Panel Data Analysis

\begin{tabular}{lccc}
\hline & Hypothesis & p value & Hypothesis Results \\
\hline ROE & H4 & 0,1293 & Rejected \\
A) Type Of Banks & H4a & 0,1760 & Rejected \\
B) Size of Banks & H4b & 0.1576 & Rejected \\
\hline NIM & H5 & 0,8542 & Rejected \\
A) Type Of Banks & H5a & 0,7211 & Rejected \\
B) Size of Banks & H5b & 0.9106 & Rejected \\
\hline
\end{tabular}

\section{Conclusion}

The effect of banks' sustainability reports' declarations on their financial performance was analyzed less in comparison with other sectors because the financial sector is excluded from samples in most of the studies. Preparing sustainability report is an indicator of sensitivity and prestige for banks. Because its standards are continuously updated, it directs them to discipline, and also it changes the way of business techniques. The changes in business techniques bring extra cost for banks. This situation also brings into question how sustainability reports affect them financially. In this connection, the aim of this study is to investigate the effect of declarations of sustainability reports to their financial situation.

First of all, questions of research in which the data between 2010-2017 of seven banks in BIST Sustainability Index were used, were determined. After that the hypotheses were set up according to these research questions.

The results of hypotheses' tests are summarized below in two different table. In Table 11 the results of non-parametric tests, in Table 12 the results of panel data analysis are placed one after the other.

Table 11: Results of Non-Parametric Analysis

\begin{tabular}{lcccccc}
\hline Groups & Hypotheses & Env & HR & PL & CI & TS \\
\hline Types of Banks & H1 & + & - & - & - & - \\
Sizes of Banks & H2 & + & - & + & + & + \\
\hline
\end{tabular}

* “+” Statistically significant at \%5 significance level; “-"Statistically not significant at \%5 significance level

Table 12: Results of Panel Data Analysis

\begin{tabular}{|c|c|c|c|c|c|c|}
\hline & Hypothesis & Results & Env & HR & PL & CI \\
\hline \multirow{2}{*}{ ROA } & \multirow{2}{*}{ H3 } & \multirow{2}{*}{ Rejected } & Negative & Negative & No & No \\
\hline & & & Relation & Relation & Relation & Relation \\
\hline \multirow{2}{*}{ A) Types of Banks } & \multirow{2}{*}{ H3а } & \multirow{2}{*}{ Accepted } & Negative & No & No & No \\
\hline & & & Relation & Relation & Relation & Relation \\
\hline \multirow{2}{*}{ B) Sizes of Banks } & \multirow{2}{*}{$\mathrm{H} 3 \mathrm{~b}$} & \multirow{2}{*}{ Accepted } & Negative & Negative & No & No \\
\hline & & & Relation & Relation & Relation & Relation \\
\hline \multirow{2}{*}{ ROE } & \multirow{2}{*}{ H4 } & \multirow{2}{*}{ Rejected } & No & No & No & No \\
\hline & & & Relation & Relation & Relation & Relation \\
\hline \multirow{2}{*}{ A) Types of Banks } & \multirow{2}{*}{ H4a } & \multirow{2}{*}{ Rejected } & No & No & No & No \\
\hline & & & Relation & Relation & Relation & Relation \\
\hline \multirow{2}{*}{ B) Sizes of Banks } & \multirow{2}{*}{$\mathrm{H} 4 \mathrm{~b}$} & \multirow{2}{*}{ Rejected } & No & No & No & No \\
\hline & & & Relation & Relation & Relation & Relation \\
\hline
\end{tabular}




\begin{tabular}{lcccccc}
\hline NIM & H5 & \multirow{2}{*}{ Rejected } & No & No & No & No \\
& & & Relation & Relation & Relation & Relation \\
A) Types of Banks & H5a & Rejected & No & No & No & No \\
& & & Relation & Relation & Relation & Relation \\
B) Sizes of Banks & H5b & \multirow{2}{*}{ Rejected } & No & No & No & No \\
& & & Relation & Relation & Relation & Relation \\
\hline
\end{tabular}

\section{Discussion and Recommendations}

In Table 11 the results of tests which analyzed sustainability performance of banks differs or not according to types and sizes of banks, are summarized.

According to our analyses, we reach the result that only the declarations about environment differ between types of banks. And also we see that the mean of the sustainability reports' declarations of private banks is more than two times bigger than public banks. This implies that private banks place especially more importance to environmental issues than public banks. We can say that the environment issue is used as an advertisement or promotion tool for prestige by private banks as this issue is one of the most delicate matter for public.

Regarding the declarations concerning human resources, product liability and the community involvement issues, we find that they don't differ between types of banks. These results show that private, and the public banks generally place importance at a similar level.

We reach the result that the declarations about environment, product liability and community involvement differ between types of banks according to our analyses. In terms of the declarations related human resources issue, we find that they don't differ between types of banks. The assets' sizes of banks can be accepted as an indicator for corporateness from the view point of management. Because of that this result shows parallelism with the study of Kılıç Et al. (2013) in which positive relation is found between the board sizes of banks and the sustainability reports' declarations of banks.

In Table 12 the results of panel data which analyzed whether the performance values of sustainability reports as environment, human resources, product liability and community involvement affect or not financial performance of banks as ROA, ROE and NIM, are summarized.

According to our analyses, we reach the result that the declarations of sustainability reports have only a significant effect on ROA. Declarations of sustainability reports don't have a significant effect on ROE and NIM.

We realized that declarations about the environment and human resources have a negative effect when we analyzed the effect of the dimensions of sustainability reports' declarations on ROA. When we add the types of banks to our model the environment has still a significant and negative effect on ROA. When we add the sizes of banks to our model, the environment and human resources have still a significant and negative effect on ROA. These results show a parallelism with the study of Kartadjumena and Rodgers (2019) in which the effect of sustainability performance on banks' financial performance was analyzed in India. This also shows that the workouts of banks on environment and human resources are just a cost object for most of the shareholders.

When we check the trend of sustainability performance in Graph 1, we see two radical changes in 2011 and 2015. We can say that until 2011 the sustainability performance is constant and low because the banking sector is interested in sustainability later than the other sectors. Until 2011 only Akbank and TSKB published sustainability report. After that between 2011 and 2015 the number of banks which published sustainability report and the number of subjects in these reports are increased. We can say that the sustainability reporting started to adopt in Turkey after this year, and as well we can show the establishment of BIST Sustainability Index in 2014 as a reason. We also see that the banks generally continued to publish sustainability reports in between 2015 and 2017. However, the number of the subjects of declaration are decreased. When we analyze this period according to Graph 2 while the number declarations are decreasing, the banks financial indicators as ROA, ROE and NIM are increasing between 2015 and 2017. This shows parallelism with our panel data results. 


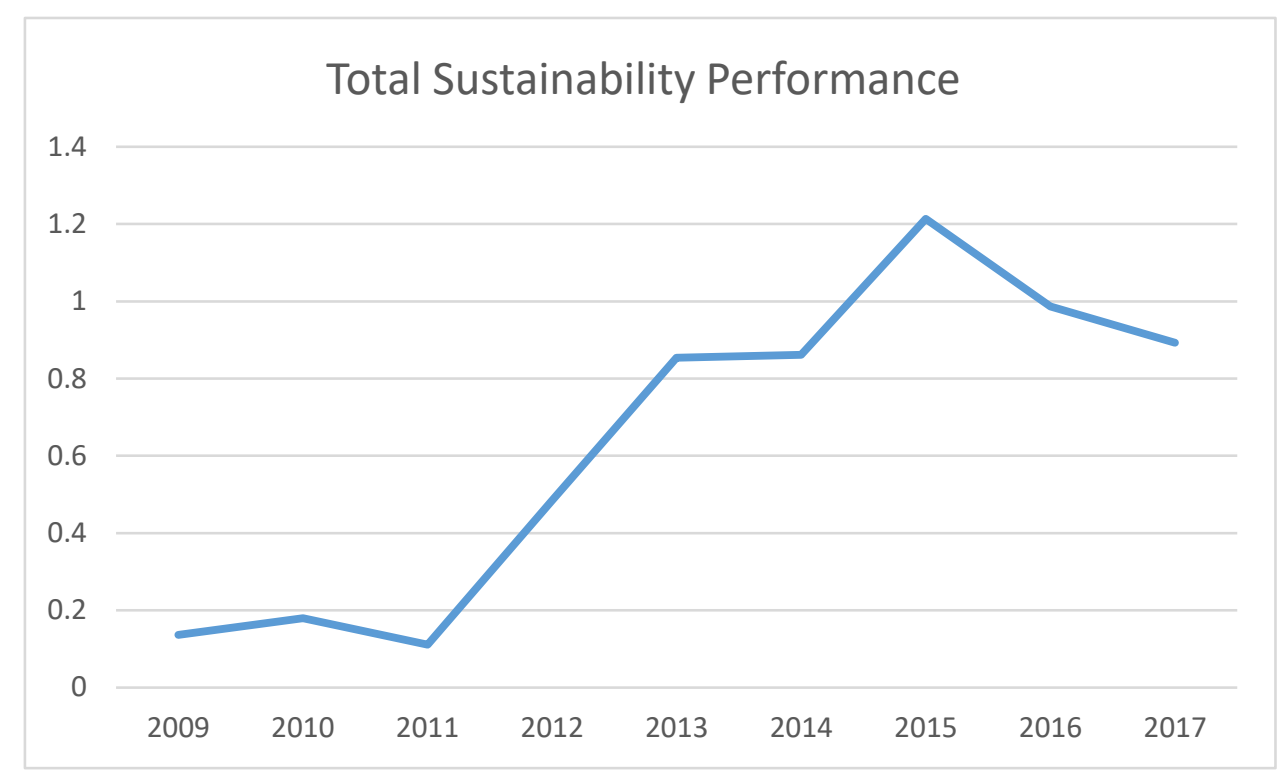

Graph 1. Sustainability Performance

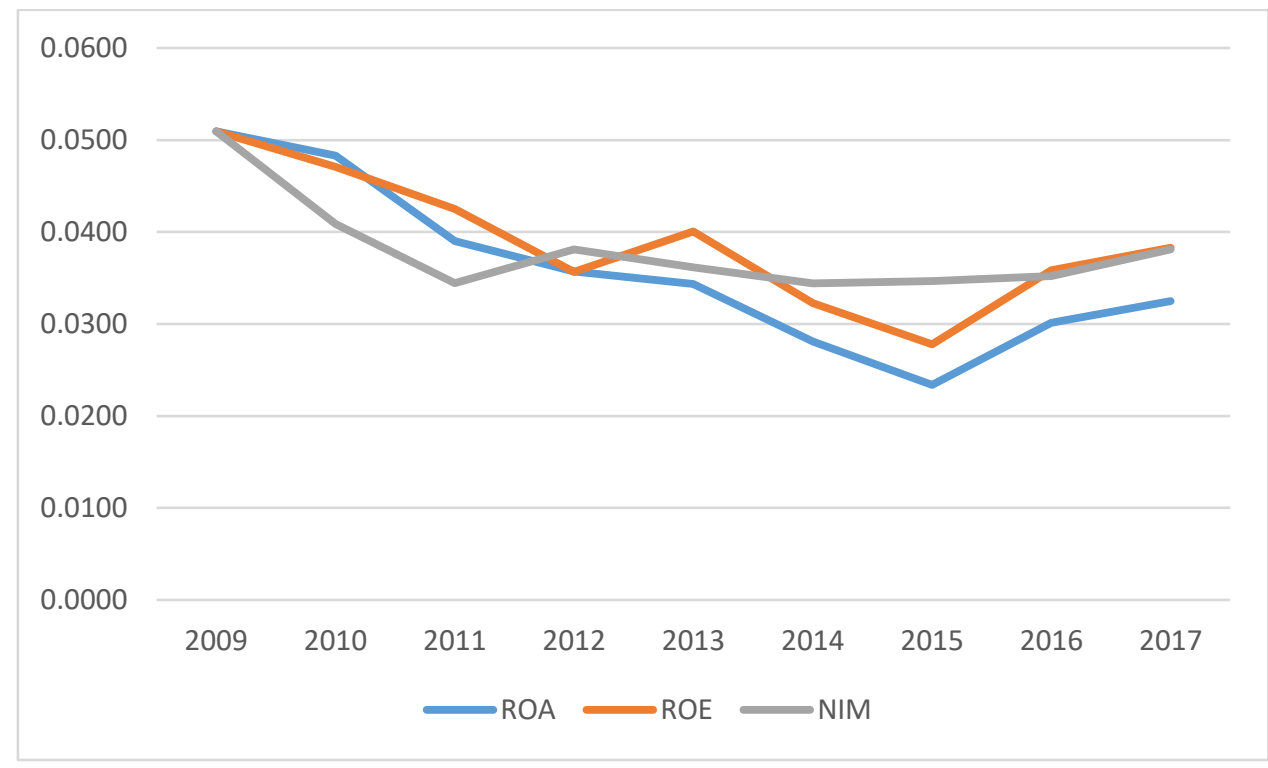

Graph 2. Banks Financial Indicators (A scale is used to show all financial indicators in the same graph). ROA-Return on Assets; ROE-Return on Equity; NIM-Net Interest Margin

There is a limited number of studies on the effect of sustainability reports on banks' financial performance, and this study contributes literature. This relationship between the sustainability reports and the banks' financial performance should be analyzed with a longer period and if it is possible with a bigger sample in the future.

Author Contributions: All authors have read and agree to the published version of the manuscript. Conceptualization, Ö.D.; methodology, Ö.D..; software, Ö.D.; validation Ö.D.; formal analysis, Ö.D.; investigation, Ö.D.; resources, Ö.D. and A.A.; data curation, Ö.D.; writing-original draft preparation, Ö.D.; writing - review and editing, , Ö.D. and A.A.; supervision, Ö.D. and A.A, project administration, Ö.D.

Acknowledgments: Thanks to Dr. Barış Kaki for his consultancy while analyzing panel data.

Funding: This research received no external funding.

Conflicts of Interest: The authors declare no conflicts of interest. 


\section{References}

1. Aggarwal, P. (2013), Impact of Sustainability Performance of Company on its Financial Performance: A Study of Listed Indian Companies, Global Journal of Management and Business ResearchFinance, 13(11), 60-70

2. Altınay, A., Kaki, B., Kestane, A., Soba, M., Dinçer, Ö. and Şık, E.(2017). Sürdürülebilirlik Endeksinin Bankacılık Sektörü Hisse Senedi Değerlerine Etkileri, Bist Sürdürülebilirlik Endeksi Üzerine Bir İnceleme, Sosyal Ekonomik Araştırmalar Dergisi (The Journal of Social Economic Research) 17(34), 208-229

3. Aras, G., Tezcan, N. and Furtuna, Ö.K. (2017). Geleneksel Bankacılık Ve Katılım Bankacılığında Kurumsal Sürdürülebilirlik Performansının Topsıs Yöntemiyle Karşılaştırılması, İstanbul Üniversitesi İşletme Fakültesi İşletme İktisadı Enstitüsü Yönetim Dergisi,

4. Aras, G., Tezcan, N. and Furtuna, Ö.K. (2018). Çok Boyutlu Kurumsal Sürdürülebilirlik Yaklaşımı ile Türk Bankacılık Sektörünün Değerlemesi: Kamu - Özel Banka Farklılaşması, Ege Akademik Bakış (Ege Academıc Revıew), 18(1), 47-62

5. Baltagi, B. H. (2005); Econometric analysis of panel data (3rd Edition), The Atrium Southern Gate Chichester: John Wiley \& Sons Ltd.

6. Buallay, A. (2018), Is sustainability reporting (ESG) associated with performance? Evidence from the European banking sector, Management of EnvironmentalQuality: An International Journal, 30(1), 98-115

7. Burhan, A. H. N. ve Rahmanti, W. (2012), The Impact Of Sustainability Reporting On Company Performance, Journal of Economics, Business, and Accountancy Ventura, 15(2), 257 -272

8. Pérez-Calderón, E., Milanés-Montero, P. and Ortega-Rossell, F. J. (2012), Environmental Performance and Firm Value: Evidence from Dow Jones Sustainability Index Europe, Int. J. Environ. Res., 6(4), 1007-1014

9. Düzer, M. and Önce S. (2018), Sürdürülebilirlik Performans Göstergelerine İlişkin Açılamaların Finansal Performans Üzerine Etkisi: BİST'teBir Uygulama, Muhasebe ve Vergi Uygulamaları Dergisi,11 (1), 93-118

10. Elkington, J. (1997). CannibalswithForks: TripleBottomLine of 21st Century Business. Chichester UK: Capstone Publishing Limited.

11. Fernandez, M. R. (2016), Social responsibility and financial performance: The role of good corporate governance, BRQ Business ResearchQuarterly,19, 137-151

12. Fettahoğlu, S. (2014), İşletmelerde Sosyal Sorumluluk İle Finansal Performans Arasındaki İlişki: İMKB'ye Yönelik Bir Uygulama, Sosyal Ve Beşeri Bilimler Dergisi, 6(1), 11-20

13. Greene, W.H. (2003); Econometric analysis (6th edition), ABD: Prentice Hall.

14. GRI, (2016). About GRI., Date Accessed : 10.11.2019. https://www.globalreporting.org/information/aboutgri/Pages/default.aspx

15. Hsiao, C. (2003), Analysis of panel data (2nd. edition), Cambrigde: Cambrigde Universty Press.

16. Kartadjumena, E. and Rodgers, W. (2019), Executive Compensation, Sustainability, Climate, Environmental Concerns, and Company Financial Performance: Evidence from Indonesian Commercial Banks, Sustainability, 11(6) 1673-1694

17. Kılıç, M., Kuzey, C. and Uyar, A. (2015), The Impact of Ownership and Board Structure on Corporate Social Responsibility (CSR) Reporting in the Turkish Banking Industry, Corporate Governance (Bingley), 15(3), 357374

18. KPMG. 2013. Survey of Corporate Responsibility Reporting

19. Lozano, R., Huisingh, D. (2011), Inter-linking Issues and Dimensions In Sustainability Reporting. Journal of Cleaner Production, 19 (2011), 99-107.

20. Madorran, C. and Garcia, T. (2016), Corporate Social Responsibility And Financial Performance: The Spanish Case, RAE: Revista de Administração de Empresas, 56(1), 20-28

21. Matuszak, L. and Rózanska, E.(2019), A Non-Linear and Disaggregated Approach to Studying the Impact of CSR on Accounting Profitability: Evidence from the Polish Banking Industry, Sustainability (Switzerland), 11(1)

22. Önder, Ş. (2018), Impact Of Sustainability Performance Of Company On Its Financial Performance: An Empirical Study On Borsa Istanbul (BIST), Dumlupınar Üniversitesi Sosyal Bilimler Dergisi; Nisan 2018, Say1 56

23. Özmehmet, D. E. (2008), Dünyada ve Türkiye Sürdürülebilir Kalkınma Yaklaşımları, Journal of Yaşar University.3(12), 1853-1876

24. Rebai, S., Azaiez, M. N. and Saidane, D. (2016) A Multi-Attribute Utility Model For Generating A Sustainability Index In The Banking Sector, Journal of Cleaner Production, 113, 835-849 
25. Report of the World Commission on Environment and Development: Our Common Future, http://www.un-documents.net/our-common-future.pdf

26. Santis, P., Albuquerque A. and Lizarelli F. (2016), Do Sustainable Companies Have A Better Financial Performance?A Study On Brazilian Public Companies, Journal of Cleaner Production 133, 735745

27. Şendurur, U. and Temelli, F. (2018), Türkiye'de Faaliyet Gösteren Geleneksel Bankalar Ve Katılım Bankalarının Sürdürülebilirlik Açısından Karşılaştırılması, Muhasebe Bilim Dünyası Dergisi,20(2), 330-346

28. Soytaş, M., A.; Denizel, M.;Uşar; D., D. and Ersoy, İ. (2017), Sürdürülebilirlik Yatırımlarının Finansal Performansa Etkisi:Türkiye Örneği, Yönetim ve Ekonomi Araştırmaları Dergisi, 15(2), 140-162

29. Telli, A. (2016), 1999, 2000, 2001 ve 2008 Kriz Dönemlerinde Türk Ticari Bankalarının Kârlılıklarının Lojistik Regresyon Analizi İle İncelenmesi, Marmara Üniversitesi Öneri Dergisi,12(45), 61-91

30. Wooldridge, J. M. (2003). Econometric analysis of cross section and panel data, Cambridge: The MIT Press. 